\title{
Two Perspectives on Family Life Through the Lens of Lodging Type
}

\begin{abstract}
This is a comparative study of two types of lodging in the transnational suspension of couples with a Romanian partner, pertaining to two distinct job categories: "low-skilled" (London, UK) and "high-skilled" (Mons, Belgium). In the course of the chapter, the difference between two strategies of living is construed, namely stealthy living and living lavishly, which underlines the impact of these strategies on transnational family members.
\end{abstract}

Keywords Low-skilled $\bullet$ High-skilled $\bullet$ Stealthy living $\bullet$ Living lavishly

\section{INTRODUCTION}

This chapter will analyze the ways of living involving Romanian "migrants," starting from the perspective of the worker category they belong to: "high-skilled" or "low-skilled." Without having these exact categories in mind, we nonetheless encountered them as such in the course of our field research in 2016, when our team members were conducting interviews with "low-skilled" migrants in London, UK, and "high-skilled" migrants in the Mons municipality of Belgium. These migrant worker categories have coalesced around our network, starting with the contact persons from the two locations. The two key migrants, both women, whom we met through our London participants, were a receptionist at a beauty salon and a housekeeper. Our hosts in Mons, who were our network heads

(C) The Author(s) 2018 https://doi.org/10.1007/978-3-319-90242-5_3 
as well, were working as civilian employees at the Mons North Atlantic Treaty Organization (NATO) base; hence, the network around them was made up of employees and contractors from this base.

For the sake of this analysis, we have selected five couples living in two houses in London and six couples living in high-end lodgings/luxury residences in Mons. All the selected participants were renting their lodgings at the time of the interview. The chapter is structured thus: after the introduction of the theoretical framework, we present the two lodging types (London and Mons), followed by conclusions.

\section{Theoretical Framework}

When researching people from Romania who choose to live in Western Europe, the best analytic filter to use seems to be that of labor migrants"high-skilled" or "low-skilled." This is because we consider the goal of these migrants to be that of working in the target country for a set amount of time in order to save up money and then to return to Romania, or eventually choosing to settle in the target country and entering the category of emigrants. The main element in initial migration is the workplace.

However, in order to understand the mobility of people from Romania toward Western Europe and the rest of the world, we need to surpass these categories, even if, for a large segment of the population located abroad at a certain moment, they retain their explanatory capacity and seek further theoretical concepts. In order to analyze the participants in this study, we needed to try other interpretive filters as well, ones that could encompass the way of living in which these persons lived in a temporarily suspended state in a transnational space without permanent anchorage in any one country: officially, they are Romanian citizens, who do not intend to definitively integrate in the host country, nor do they nurture return projects; thus, they are always juggling between being citizens of one country and living in another or several countries, mixing social and judicial rights and obligations between these countries.

Our subjects are couples who either left Romania together or came together while one or both partners was/were abroad.

If, for some of members of these couples, at a certain moment the motive to migrate was to work abroad-except the partners in one particular couple (Sanda and Ovidiu) - this decision did not come about as a result of not finding work at home, which met their qualification level, but rather as a result of wanting a "better life" (Benson 2011). We can hardly 
view Sanda and Ovidiu through the prism of temporary migration for work, since their wish, in the future, when they decide that they have had enough of the UK, is "to move to some country where the climate is better" (Sanda). Rather, in order to understand them, we need to refer to the concept of lifestyle mobility, which means "to move on, rather than move back" (Cohen et al. 2015). The other three couples in London-with the exception of the aforementioned Sanda and Ovidiu, as well as Rodica and Levi, who had a professional and material life in Romania in direct proportion to their qualification level, but wanted more, both in financial terms and in terms of living - had not even started their professional life project in Romania, but moved abroad when they were very young. Besides this, out of the participating five couples in London, Rodica and Levi were the only ones who would eventually consider coming home to Romania. Concerning their occupation, except for the women (Maria, Rodica and Sanda), who had jobs inferior to their professional status or what they used to do in Romania previously, the other migrants in London, although low-skilled-meaning they had jobs that did not require specific professional training-were not below their level of qualification or below what they could have had as a job in their country of origin.

Concerning our participants in Mons, although up to a point we could use the category of high-skilled migrants, we were limited by the specificity in terms of conceptual content, as in the case of low-skilled migrants. True, a large majority of the participants in Mons transferred skills across national borders (Ryan and Mulholland 2014), but we could better analyze them through the prism of the "capability approach," which surpasses the "standard" economic view of highly skilled migration (Cencei 2015), given that all participants in Mons (including those who do not work abroad at present) had enjoyed a professional and social life of a high standard. The women also belonged to these privileged categories in Romania (Laura, Dana and Atena) and proved to be worthy of high positions abroad, highlighting the results of other studies that show the rise in the numbers of high-skilled women in the context of migration (Docquier et al. 2009). The three women who either did not work at all (Mariana and Elena) or did so at the level they used to work in Romania (Krisztina) had not decided to do this out of a lack of opportunity, but in order to pay more attention to raising their children; hence, they "regard themselves as active players in family migratory strategies" (Ryan and Mulholland 2014, p. 597). Their decision to move was only partly connected to financial opportunity, while they regarded the time spent in Mons "as a prolonged 
vacation" (Mariana), especially since the majority of jobs or contracts with the NATO base were for a set period and extended periodically, just as in the case of other high-skilled migrants (Ryan and Mulholland 2014). Besides, the opportunity to make trips and simply live in the West-as a new life experience-had been the leitmotif concerning decisions to move to Mons among our participants.

This kind of temporary habitation, which hardly, if at all, emphasizes the economic aspect, is rather a life project, which up to a point resembles other categories: Eurostars or free movers (Favell 2013) and lifestyle migrants (Benson and O'Reilly 2009; Benson 2010; Casado-Diaz 2010). That said, these concepts have somehow only been associated with Western citizens, who move to another country; hence, they are difficult to associate with Romanians. These concepts are difficult to delineate and operationalize in such a way as to provide them with a consistent explanatory power, while demarcation lines between categories are sometimes hard to draw, as in the case of lifestyle migration versus labor migration, when talking about the impact of the economic crisis upon one or another category (Huete et al. 2013). If the first category, that of free movers, is somehow associated with the desire to excel professionally, the second, lifestyle migration, is rather associated with a break from professional life, although none is so strictly delineated, while, in numerous studies on lifestyle migration, it has been shown how they supplement their income through locally developed businesses. Another concept grasping this temporality - the one that is closest to the experience of our participants-is that of liquid migrants (Engbersen 2012; Engbersen and Snel 2013); however, we shall notice that although we encounter postponement of childbearing in two situations in London (the couples of Rodica and Levi as well as Sanda and Ovidiu), children are still present in many cases, and the responsibility to the extended family is maintained-as research on other migrants has also shown (Bygnes and Bivand Erdal 2017). Indeed, with the exception of Sanda and Ovidiu, whose future plans include open options, the plans of all the others remain suspended between returning to Romania and staying in the destination country.

A much more explicative approach for understanding the various life strategies that people employ under the influence of migration is the analysis of its impact upon the type of lodging. From staying in the house of the person one is attending to, as in the case of many migrant domestic care providers, or from residing with several other persons in a single room, as in the case of many workers engaged in temporary low-skilled 
labor migration, to spending long periods in luxury hotels, as in the case of many people from the high-skilled category, represent life situations that provide additional explanatory information to life narratives. Belonging to a transnational family even influences the way of lodging in the country of origin, along with an impact on the way in which families are organized. We are dealing with an example of the reorganization of gender roles through increased involvement from women at home (Pauli 2008) or from those involved in migration (Iacob Larionescu 2016) in both the design of a home and the construction process.

In this chapter, we shall present two life strategies directly linked to the way in which couples, who are in a certain sequence in their mobile transnational life, are lodged. Lodging strategies contain a set of concentrated family practices (Morgan 2011), such as investing money and time in lodging space and interior design, to be shown to guests from the community or to relatives, in order to demonstrate being together, or, in other words, a set of practices linked to lodging, such that these couples can present themselves as couples in front of an audience formed from the community and their families (Finch 2007, 2011). The first set builds the strategy of stealthy living for the couples in London, who, through the decisions linked to their mode of lodging, minimize their exposure as a family toward the community they live in, but also toward the members of their extended transnational family. On the other hand, we find the strategy of living lavishly among the couples in Mons, who, through their expansive and somewhat opulent mode of lodging, are situated in a position of superiority compared to the community they live in, and involve members of their transnational family in their way of life to a very high degree.

\section{A Strategy of Stealthy Living}

\section{London}

At the very beginning of the arrangements for the London fieldwork, when trying to create a network, we were surprised by the following phrase coming from our local Romanian contact: "It is a ghetto and Romanians live there. We live somewhere else." This was in reference to the neighborhood of a friend's home, where the research team had just declared they would stay. Actually, the friend was Irish, highly skilled and living in an expensive and especially central area. We continued receiving this type of localization from other Romanians in ghettos through our 
fieldwork there. It is very interesting that the snowball method did not work out in London. Each time we found a thread involving Romanians who shared lodging, the thread would break. Our Romanians were friends with all kinds of other migrants, with an openness to postnational relationships (Kennedy 2010), but declared that they did not know other Romanians, since they were "living elsewhere, in a ghetto." To be frank, the interviews that were conducted in the houses in London where Romanians lived took place on the peripheries, far away from the center. Another series of interviews took place in public places, under the pretext that we should meet halfway, although we felt that the participants did not want to show us their places. Even the two houses mentioned so far were in two peripheral areas. None of the five couples had personal cars; rather, they were mainly using the famous red London buses, which are cheaper than the Underground.

House 1-three bedrooms, two bathrooms, one kitchen and one small living room. The third bedroom has been split from a former large living area. A small courtyard.

Inhabitants—three childless couples:

Sanda, a receptionist at a beauty salon, and Ovidiu, a hired laborer at a small manufacturing workshop. They are about 35 years of age and do not want to have children, since they are unsure about their future following the upcoming (at the time of the fieldwork, potential) Brexit. They could stay in England or move to another country; returning home to Romania was not an option. They used to live in a large city back in Romania.

Rodica, a nanny at a kindergarten, who used to be a kindergarten teacher back home, and Levi, a construction worker. They are both about 40 and without children. They are minded that, if they return home in the next few years, they will perhaps have children. Back in Romania, they used to live in a middle-sized town.

Maria, a salesperson, and András, an electrician; they are aged 23 and 25, respectively. They married two years ago and are going to move into a house outside London by themselves, which they bought with help from András' parents since they want children. They used to live in a large city in Romania and were schoolmates. András moved to London aged 14 with his parents. 
The house in which the three couples live was rented and managed by András before marrying Maria. He modified the living room and subrented it to the other two couples. Now that he is moving out, Levi is taking over its management. He needs to find a tenant for the free room, establish new house rules and maintain contact with the owner. The present house rules are (1) the landline is to be used by András and Maria only; (2) only András and Maria may have pets (namely, a dog); and (3) no one may have overnight guests. If someone wants to be visited by family members for a few days, they need to rent another place for them for that amount of time.

House 2-two bedrooms, two bathrooms, one large living room, one kitchen and a small courtyard.

The official inhabitants were two lone mothers, who were staying there with their children (they were not married to the respective fathers, who remained their partners). Unofficially though, their partners were staying there. The men had their personal belongings hidden in case of an unforeseen inspection by the welfare authorities, so that the support given to the mothers was not affected. The decision to hide the fathers was made on the basis that single mothers receive much more substantial welfare support than married mothers. Moreover, while Katerina and Adi had a rather unplanned parenthood, Geta and Cornel had planned to have their child in order to receive this very money. The two couples were very proud that, through this arrangement, they could afford to live in a spacious home.

Adi and Katarina (from Romania and Latvia, respectively), aged 23 and 22 , with one seven-month-old daughter. Adi, until two years ago, when he met Katerina, was a shell game player, which, although officially a focus game, is really a way to deceive passers-by and take their money. $\mathrm{He}$ is now a qualified construction worker. Before giving birth, Katerina was a waitress in a bar. They both come from small towns in their respective countries.

Cornel and Geta, 20 and 19 years old, respectively, with one boy of five months. Cornel is a construction worker and Adi's colleague, while Geta is only a mother. They both come from the same small town in Romania. 


\section{Lack of Openness Toward Family and Community}

No grandparent has come to visit the two newborns in the UK. The parents had been planning to travel home with the children to submit their papers for Romanian citizenship. For the moment though, because they did not have any citizenship, they would have been unable to come back to the UK if they left.

These families in London visit their family members in Romania rarely-once a year on average-for financial reasons; they are also rarely visited in the extreme by family in London, especially since they usually cannot provide them with housing there. On the rare occasions when some of them have family visitors, as in the case when Sanda's brother came to London for a few days with his fiancée, in order to provide accommodation for their relatives, Sanda and Ovidiu rented another apartment for a week, where they stayed with the relatives.

Financial support for those at home is provided only when needed and to a limited extent (in the case of illness or unforeseen expenses). The little money they manage to save is for the future. The three women who work out of the five perform jobs that are well below their qualification level: Sanda has a PhD in anthropology but works as a receptionist; Rodica is a qualified kindergarten teacher and did work as one in Romania, but is now nannying in a crèche in the UK; and Maria is a qualified accountant, but is working as a saleswoman. Moreover, Sanda and Rodica especially feel that any kind of professional success is extremely difficult for them as Romanians during this pre-Brexit period.

In terms of community, our London participants had, as we have mentioned, no relationship to any other Romanian migrant. The only friendships they mentioned involved other, non-Romanian migrants, but their interaction went no further than work (there were no mutual visits to their homes). Their attitude toward English Londoners is one of inferiority, and one of dissociation toward other Romanians, a feeling informed by the campaigns of criticism against Romanian migrants in the context of Brexit. Many have internalized these feelings, as if the English, seen as superior to them, were implicitly right, while other Romanians from the same low-skilled category, who were targeted by this criticism (except themselves), could only be as the critics say: uncivilized and unfit for the UK. 
You don't quite see them (English Londoners), they don't walk on the street nor ride the buses. They travel by car. Buses are full of migrants, and above, on the front seats, you will always hear loud Romanian talk. That is the way Romanians are, they jab up front and are noisy. When I see them I always pretend not to speak Romanian. (Rodica)

Hiding from the community they live in can be observed, especially in the houses with "lone mothers," where men live undercover. Of course, this kind of accommodation of couples who are not couples in the eyes of the authorities, for the sake of receiving the status of being a lone mother, is not specific to Romanians, but comes from British society. That said, it is becoming increasingly popular with a category of young Romanians who decide to live in the UK for a while in the context of this type of couple management.

It is especially hard to imagine a family future, given the situation of the inhabitants of this house. How long will they hide in the UK? How long will legislation encourage this kind of lodging, especially in the context of Brexit? Will they return to their countries of origin? What will happen in the case of the binational unofficial couple? These are questions that couples have refused to answer, as they are optimistic that this temporary situation will last for decades, by which time they will have raised their children.

The future of the couples in the first house is differentiated. Maria and András seem to be inclined to removing themselves from transnational suspension through integration. András has been raised there and has family in the area; he plans to move into his own apartment. To be sure, this couple will maintain a transnational relationship with members of Maria's extended family, who are still in Romania, and the direction their life is headed is assimilation into the community they live in. Their temporary transnational life together has been a kind of test for the couple, since their relationship before getting married was conducted through the internet and by phone. András, who initially lived with his parents, rented this house and managed this type of lodging once Maria came to London. Levi and Rodica, who also shared lodging space with other couples before moving to this house, are to take over the management of the house after András' departure and look for a couple to fill the vacant room. In the near future, they are to maintain this type of existence, while, in the more distant future, they imagine returning home, especially given that they have their own apartment waiting for them in Romania. 
Ovidiu and Sanda, even if they see their future in the UK in the short term, are worried by the threat of Brexit and are considering moving to another country before retirement-anywhere but Romania.

This type of lodging underlines how temporary and transnationally suspended the lives of these couples are, as they do not fully belong to any of the two societies. It is as if, during these years, running into decades of camouflaged living, these families held their breaths and were somehow put on hold in terms of family existence toward the audience: a kind of nondisplaying family, contrary to what Finch (2007) defined as a displaying family. For me, this result is especially interesting, since during my research on the transnational motherhood of Romanian women, I found that it is precisely the wish to display that the transnational family, of which they are a part, is functioning well-just as in the case of other questionable families under pressure from heavy discrimination in Romania-which forces these families to make additional efforts in order to fulfill the transnational mother-child relationship (Ducu 2013, 2014). A possible explanation could be that displaying questionable families becomes amplified under the impact of discrimination (Fox et al. 2015) if the members of these families deem it unfair. It seems that in the case of internalizing external discrimination, the effect upon families undergoing this discrimination is to camouflage themselves as perfectly as possible. We encountered the most powerful impact of internalized discrimination in the UK in the case of Sandu (who is not part of the couples presented in this chapter), who, having stayed for 12 years in London, has managed to rise to a good social position and was deeply concerned by the recent wave of Romanian migrants, sharing the views articulated in the press concerning Romanians as inferior to others and wishing that the UK exits the EU in order for Romanians not to be able to come over as easily, so that he will no longer be confronted by discrimination. Like Sandu, almost all respondents in the London fieldwork, including the couples presented in this chapter, considered discrimination against Romanian migrants in London to be justified. Camouflaging these families is, hence, not a life objective, but a life strategy. 


\title{
A Strategy of Living LaVishly
}

\begin{abstract}
Mons
The couples who were childless or with young children were living in duplexes or high-end apartments in Mons, all of about $100 \mathrm{~m}^{2}$ in size. Where the children were older, the parents chose to live in one of the satellite villages of Mons in order to be able to rent larger houses, with more generous courtyards and at shorter driving times from their schools. The most interesting aspect is that the Mons recommendation network worked perfectly, with all respondents in this fieldwork connected in one way or another. Hence, all six couples presented here are, in a way, part of the same network of acquaintances. Moreover, while in Belgium, we also took part in two celebrations at the houses presented below, with the participation of part of the respondent network. Each couple possessed two cars.
\end{abstract}

\section{Mons: City}

House 1-a duplex with a large living room, one kitchen, two bathrooms, three bedrooms, a large attic, used as a painting workshop by Codrin, and a small courtyard.

Laura and Codrin. Laura was a contractor for the NATO base and Codrin was a painter. Both came from a small town in Romania. Laura was the first to settle in Mons. She met Codrin in Brasov, Romania, after she moved to Belgium, and after a transnational relationship, he would move in with Laura there-only one year before the interview. She was using the extra space in the house in order to organize periodic reunions of her spread-out family: only her parents remained in Romania. Her sister had moved to Canada with her husband and two children. She not only offered accommodation, but always paid for her parents' trips from Romania-low-cost airlines have made these sponsorships possibleand sometimes helped her sister with her expenses to fly her family from Canada to Belgium. When Laura's mother needed a surgical intervention, she immediately flew home. She took her to a private hospital in the capital and paid for the best possible treatment. The housekeeping was provided by a Filipino lady. 
House 2-a high-end apartment: a large living room, a kitchen, two bathrooms and two bedrooms.

Dana and Ottho. They are both civilian employees on the base. Dana comes from a middle-sized town in Romania, while Ottho comes from a middle-sized town in Germany. They met at work in Belgium. His parents very rarely come to visit. On the other hand, Dana's mother visits frequently and stays at their place. Dana helps her with the travel expenses. Being Dana's only close relative, she likes her to be as close as possible. Ottho has learned Romanian and can communicate with his mother-in-law. The mother's visits in Belgium are good opportunities for the three to travel around Belgium. It is easy to get to the North Sea, Paris and so on from Mons.

House 3-a duplex, an office, two bathrooms, two bedrooms, a large living room, a kitchen and a small courtyard.

Atena and Radu. They have one daughter, aged one. They are both civilian employees on the base. Radu was the first to be employed, after which he met Atena on his visits to Romania. Atena followed him. She did not work for one year, but then managed to find employment and now she also works at the base. They both come from a middle-sized town in Romania. Their little girl was born in Belgium and goes to the American crèche on the base. Their relatives from Romania visit them periodically, but they also go home very frequently. They have a lowcost airline route to their native town. They go especially on weekends. They always travel without luggage, since they have everything in Romania, from clothes to toys. Since they spend so much time in the country, they decided to buy an apartment there, which is managed by their relatives in Romania. The office, with its own bathroom, is used as a guestroom during weekends or during the week, if needed, for relatives or various members of the network who choose to spend the night at their place. Moreover, among the frequent guests are a couple, comprising an ex-neighbor from Romania and her present partner, who live in Louvain, but do not belong to the elite category of those working for the NATO base: she is a simple kindergarten teacher and he is a plumber. However, they have a special relationship with the daughter and are considered as a kind of aunt and uncle. Such a relationship would probably not have had developed if they had only been neighbors from Romania. An Italian housekeeper cleans the house. 


\section{Mons: Ruval Zone}

House 4-a large house with five rooms, a kitchen and a very large courtyard. The way it was furnished and arranged shows Krisztina's passion for interior design.

Krisztina and Gabriel. They have a 12-year-old son and a 5-year-old daughter, who were born in Belgium. Gabriel is a contractor on the base. Krisztina now works part-time as an insurance consultant, but although in Romania she had a career on the rise when she came to Belgium eight years ago, she stopped working and did not take it up again for many years. She chose not to work or to work very little in order to have time for their first child, and then both children. Beyond schooling, there are many possibilities in Belgium for extra activities so that a full-time job would not have allowed her to organize their children's extracurricular time. Of course, the free time she enjoyed allowed her to take care of the house as well. The two have bought a plot of land in the area and have started to build their own house in order to stop renting.

House 5-a huge living room, two bathrooms, a kitchen, three bedrooms and a very large courtyard.

Mariana and Vlad. They have a son aged eight, who was born in Romania; they have been living in Belgium for five years. Vlad is a base contactor, while Mariana, who used to be a bank manager in Romania, is not working in Belgium. They both come from a middle-sized town in Romania. For Mariana, the time in Belgium (she is uncertain as to its duration) is like a long vacation. She spends much time with the child. They make many trips around Belgium, as well as go home quite often for the sake of the child's relationship with their parents. At home, they have a large house, which stays uninhabited and is managed by the boy's nanny from the time they used to stay there. Although they have left, they are still paying the nanny to take care of the house. This is so that they have a clean home and food when they return to visit Romaniasince they frequently fly there on low-cost airlines-as well as to take care of their child when they are in Romania. The big house in Belgium allows them to entertain their child's friends (the children of Krisztina and Gabriel) very often, and even host them overnight if the parents 
need this kind of help or the children would like it. At the precise moment of the interview, Mariana had learned that her mother was to undergo surgery. She decided that she would probably leave for Romania immediately after she agreed with Krisztina about how to take on her son's supervision, given that her husband cannot afford to stay alone with him due to his full-time job.

House 6-one large living room, two bathrooms, one kitchen, four bedrooms and a large courtyard.

Elena and Dorin. They have a five-year-old son, who was born in Romania, and a daughter, aged 18 months, who was born in Belgium. They both come from a small town in Romania. Dorin is a contractor on the base. Elena used to be a specialized engineer for a private company in Romania, but has not worked since she came to Belgium in order to take care of the children. She regrets this decision, since she liked her profession very much. She knows that she could not manage the children if she worked: the boy goes to a school in the village they live in, but the girl attends an international kindergarten in Mons. The boy also goes for various extracurricular activities. She is making plans to go back to work once the children are older. She has identified a large factory outside Mons with the same profile that she is trained in, and hopes that someday she can start working again. The extra room they have is a guestroom. All the members of the network who live somewhat farther away, or do not feel like going home, can stay with them overnight. It seems that this is very welcome, since the guestroom is always busy during weekends. Elena is very happy about this because it allows her to maintain stronger relationships with other adults, given that she spends a lot of time with the children, although she has an adult to help her out during weekends. Thus, they fill in for the lack of the relatives' help (grandparents and aunts), which they would have received at home. Of course, the guestroom is also given over to these relatives who do visit them from time to time, but, since all four grandparents have full-time jobs in Romania, the visits are not as frequent as they would wish. 


\section{Openness Toward Family and Community}

The participants from Mons whom we have presented have a great deal of freedom in maintaining physical contact with their extended families: they have the money to travel and pay for other family members' trips, as well as have the space to host them. Monthly visits between Mons and Romania have been mentioned, alongside vacations organized for family members in Mons. They can afford to offer quite a strong support to their families at home.

They manage to maintain consolidated relationships with fellow Romanians. The community of Romanians collaborating with the NATO base is extended and intersects with that of Romanians collaborating with the European Parliament in Brussels. The specific types of interactions are very diverse: from supervising each other's children, through getting involved in changing or redecorating each other's lodging, to weekly parties.

Concerning interaction with the extended community in Mons, our participants belong to a community of expats from around the Mons NATO base whose incomes are substantially different from other locals. They rent the best lodging and make use of community services, such as house-cleaning firms and private kindergartens. Up to a point, we could say that, on a symbolic social scale this community is situated at a higher level than that of locals, as in the case of lifestyle migrants (Benson 2010), and "they remain in many ways outsiders, positioned from the outside as elite (in terms of material and economic privilege)" (Torkington 2012, p. 88).

The community of expats around the NATO base in Mons is very large and continuously changing-many of the collaboration contracts are changing, too. Hence, as I said, there is a steady circulation of people in the short term. The real estate market in Mons takes advantage of this permanent flux, especially in terms of rents and interior design. Ikea has opened a store in the area, and our participants were among its frequent customers. Among the members of the network studied in Mons, which encompasses participants who are not presented in this chapter, it's only twice that we encountered a wish to buy property in Mons. The couple Krisztina and Gabriel bought land upon which they were building a house. Tudor, another participant in our research, already had three real estate investments in the area. This reluctance to buy property is closely correlated with their suspension in temporary transnationalism. On the one 
hand, they were only collaborators for a set time frame; hence, they were Romanian citizens with no intention to move to Belgium. On the other, their contracts are quite often repeatedly renewed; hence, the set amount of time keeps extending over the years. The decision to buy properties is not correlated with a wish to integrate, but rather with a real estate investment.

The fact that they collaborate with the NATO base represents their main source of income, which can best be observed in the relationships in which the women do not collaborate with the base. In these cases, they prefer not to work at all, since their partner's income suffices for a decent living. However, given that these women used to have a good professional life in Romania, this experience of not committing to their profession anymore, even if only stated by Elena, is still a shortcoming alongside the many advantages of belonging to a high-skilled family. Krisztina told us how, in her first year in Belgium, with her son not yet in school and not knowing that more years of living there would follow, she quite literally felt as if she was on vacation: they made daily trips together to the surroundings, and longer ones with her husband. But then her husband's contracts kept getting extended. The child went to school. Then his little sister appeared, who then reached kindergarten age. Each contract comes with a new set time frame, on which they base their short-term plans. Mariana also refers to the years spent in Mons as a vacation. There is a trip almost every weekend, except those weekends that are spent in Romania. The children go to school there, but each year could be their last in Belgium. Elena, Mariana and Krisztina, who work part-time, spend most of their time with the children-kindergarten or school, as well as other activities - or with interior design. For example, Krisztina's home is very beautifully furnished with antiques she has made an effort to collect from various places.

Let us note that the future of the above participants is completely unsure. They do not make long-term plans. In spite of the comparatively happy life they lead, I have felt that the recurrence of a "set time frame" throws a shadow of bitterness over the community. The topic kept turning up among our participants, especially since they were all in different phases of their contracts. For example, Laura had been without a contract for several months when our team arrived to Mons, which is why she was assigned to be our guide - she collected us each morning and drove us to the locations where we recorded our interviews. She was among our first respondents and declared in an interview that she had extended her rent 
by six months; but, if her contract were not to be extended, she would move back to Romania. Overnight, she eventually learned that her contract had been extended. The next day Atena became our guide, taking leave from work to do so. Maria's husband Vlad's contract was expiring in a few months, and they were undecided as whether to extend their rent in Mons while waiting for an extension or to move back to Romania and then return, if needed. Gabriel's contract had just been extended a few months earlier, after a very short pause; hence, they decided to buy the plot of land and build a house immediately after getting their collaboration with the base extended.

This period of temporary transnationalism, as lived by these couples, may be understood as a pair of parentheses around their lives, a bubble containing something else that gets extended for an undetermined period. Given that they belong to a community of expats, for these couples, it is an occasion of pride to feel part of a special community, which stands above the local one. Of course, they belong to rather high class at home too; but, being superior to Westerners is a real reason for content among these Eastern Europeans. All these accommodation practices-big houses, constantly redesigned; a cleaning service; childcare; hosting other Romanians in Mons, especially their extended families-allow them active interaction with the audience (Finch 2007, 2011) and take shape in what is called displaying the family. This is a way of saying: this is us, we made it at home, and we made it in the West too.

\section{Conclusions}

We are becoming increasingly conscious of the fact that the "asymmetrical skilled migrations within the EU touch on problematic aspects of EU integration" (Cencei 2017), but we are much less conscious about the way this asymmetry is reflected in the lives of those living in a state of temporary transnational suspension within the EU.

Drawing upon what has been described as "a mobile life-strategy for creating a sense of feeling 'at home' in order to compensate for having no real sense of physical, cultural or ancestral ties with the place in which they have chosen to live" (Torkington 2012, p. 89), in this chapter, we have presented two strategies of living, both temporarily suspended in the transnational: a strategy of stealthy living and a strategy of living lavishly. In the delimitation of these strategies, I have drawn upon the model comprising "a three-part typology of Euro-commuters - 'survivors', 'thrivers' 
and 'strivers' - based on their principal motivation for undertaking this mobility" (Ralph 2015 , p. 37), but I have centered on the differentiation between the two ways of living in terms of lodging type. Ralph (2015) has shown how a partner's mobility type has an effect on the entire couple, as well as reflects on the perspective of the partner at home. In my approach, I chose couples as a direct object of analysis and emphasized, together with Ralph (2015), how belonging to one category or another impacts the gender roles in the couple, which is an issue we shall return to in this concluding subchapter.

I have illustrated the strategy of stealthy living by presenting the mode of lodging in London among five couples in two houses on the outskirts. These couples also have in common the fact that they are performing unskilled work. Given the location of their lodging outside the city center, as well as having to travel by bus and the physical restraint of their lodging space (each couple literally has a single room for personal use), these couples radically limit their relations with the community they live in, including their extended transnational family, which is a way of nondisplaying the family, probably under the influence of their discrimination within the UK.

I have developed the idea of living lavishly in relation to six couples belonging to a community of expats around the NATO base in Mons, who live in six luxury residences, initially in the town center in apartments or duplexes, then, as the family extends, moving toward the more rural area of Mons, accessing larger houses with more generous courtyards. The expansion of these couples' lives, in terms of a larger living space, two cars per couple and the use of cleaning and childcare services, gives them a clear profile within the community, as well as the physical involvement of their extended family in their way of life; in other words, the intense displaying of these families may also be associated with the pride taken in their way of existence.

Through the present comparison between the two temporary transnational lifestyles, I was able to capture the way gender relations are reflected differently, depending on the category that the couples are a part of, and answer to the appeal that Brettell (2012) has made toward researchers in the field to apply such comparisons when researching gender relations within transnational families.

The most visible impact of the mode of lodging and gender relations for the couples can be reflected in the role that children play within the existence of these families. In London, due to the limitations of lodging 
space, we may witness, on the one hand, the phenomenon of indefinitely postponing the decision to have children (inhabitants of the first house) or, on the other, a mode of lodging that is structured around the children, as in the case of the "single mothers" (in the second house). In Mons, we have noticed that the childless couples or those with young children live in urban areas in smaller homes with a small courtyard (in apartment buildings or duplexes); but, when the children grow and more children appear, they move to the rural area with larger homes, especially those with courtyards where the children can play. The lack of children is associated with women's active involvement in work at both sites, with the presence of children clearly meaning women's withdrawal from the labor market. Katerina used to work in London before having a little girl, but then she gave up work and contented herself with the status of a "lone mother." Meanwhile, in Mons, Elena and Mariana do not work, and Krisztina, who now has a part-time job, used not to work for a long time after moving to Mons, although all three previously held prestigious professional positions in Romania, even while each of them was raising a young child.

Regarding active women, we observe a clear difference in maintaining their initial professional position between the two categories of women from the two sites. Sanda, Rodica and Maria (first house) in London have, as we have pointed out, undergone a process of de-skilling through moving from Romania to the UK, occupying positions that are professionally inferior to their training and to those previously held roles in Romania. In contrast, women in Mons maintain their professional positions at similar levels to those in Romania, and being professionally equal to their partners, as in the case of Dana and Ottho or Atena and Radu, or even superior, as in the case of Laura and Codrin.

Before going further, I would like to underline again that the two temporary transnational living strategies, stealth and lavishness, are not typical for all the Romanians living at the two sites. We did not have any highskilled Romanians as respondents in the London research, even though they are numerous; hence, we were unable to address their way of living. There are also many low-skilled Romanians in Mons (we even engaged with them at a Romanian store), whom our respondents said were working in construction, but we did not involve this group as respondents in order to understand their lodging habits. Moreover, in London we have respondents who live in the same house, whereas in Mons, respondents who don't just live in the same area, but are connected through the workplace of some of the partners (the NATO base), as well. This comparison 
between two different categories of people in two different locations represents a limit to the approach. One question that could be raised is whether their contextual surroundings or their different job categories determine the differences between their transnational practices. The answer is both, given that workplace category determines the type of lodging, implicitly determining the type of the couple's practices.

I consider that more research on the relationship between lodging and life strategies, especially of those who live in a state of temporary transnational suspension, could provide us with useful information through which to understand the effects that temporary mobility has on the existence of families in this situation.

Funder: Executive Unit for Financing Higher Education, Research, Development and Innovation (UEFISCDI), project code: PNII-RU-TE2014-4-2087.

\section{REFERENCES}

Benson, M. (2010). The Context and Trajectory of Lifestyle Migration. European Societies, 12(1), 45-64. https://doi.org/10.1080/14616690802592605.

Benson, M. (2011). The Movement Beyond (Lifestyle) Migration: Mobile Practices and the Constitution of a Better Way of Life. Mobilities, 6(2), 221-235. https://doi.org/10.1080/17450101.2011.552901.

Benson, M., \& O'Reilly, K. (2009). Migration and the Search for a Better Way of Life: A Critical Exploration of Lifestyle Migration. The Sociological Review, $57(4), 608-625$.

Brettell, C. B. (2012). Gender, Family, and Migration. In M. R. Rosenblum \& D. J. Tichenor (Eds.), Oxford Handbook of the Politics of International Migration. https://doi.org/10.1093/oxfordhb/9780195337228.013.0020.

Bygnes, S., \& Bivand Erdal, M. (2017). Liquid Migration, Grounded Lives: Considerations About Future Mobility and Settlement Among Polish and Spanish Migrants in Norway. Journal of Ethnic and Migration Studies, 43(1), 102-118. https://doi.org/10.1080/1369183X.2016.1211004.

Casado-Diaz, M. (2010). Exploring the Geographies of Lifestyle Mobility: Current and Future Fields of Enquiry. In J. Wilson (Ed.), The Routledge Handbook of Tourism Geographies. New York: Routledge.

Cencei, A. (2015). A "Capability View" on Migration: Some Theoretical Issues Raised by the Southern Euro Zone Highly Skilled Mobility. Innovation: The European Journal of Social Science Research. https://doi.org/10.1080/13511 610.2015 .1024636 . 
Cencei, A. (2017). A Qualitative Viewpoint on the Southern Eurozone Highly Skilled Labour Mobility in the Metropolitan Area of Copenhagen in Times of Crisis and Austerity. Mobilities. https://doi.org/10.1080/17450101.2017.13 83665 .

Cohen, S. A., Duncan, T., \& Thulemark, M. (2015). Lifestyle Mobilities: The Crossroads of Travel, Leisure and Migration. Mobilities, 10(1), 155-172. https://doi.org/10.1080/17450101.2013.826481.

Docquier, F., Lowell, L., \& Marfouk, A. (2009). A Gendered Assessment of Highly Skilled Emigration. Population and Development Review, 35(2), 297-321.

Ducu, V. (2013). Romanian Migrant Women's Response to Their Discrimination. In T. Geisen, T. Studer, \& E. Yildiz (Eds.), Migration, Familie und soziale Lage: Beiträge zu Bildung, Gender und Care (pp. 195-123). Cham: Springer.

Ducu, V. (2014). Transnational Mothers from Romania. Romanian Journal of Population Studies, VIII(1), 117-141.

Engbersen, G. (2012). Migration Transitions in an Era of Liquid Migration Reflections on Fassmann and Reeger. In M. Okolski (Ed.), European Immigrations, Trends, Structures and Policy Implications (pp. 91-107). Amsterdam: Amsterdam University Press.

Engbersen, G., \& Snel, E. (2013). Liquid Migration: Dynamic and Fluid Patterns of Post-accession Migration Flows. In B. Glorius, I. Grabowska-Lusińska, \& A. Kuvik (Eds.), Mobility in Transition: Migration Patterns After EU Enlargement (pp. 21-41). Amsterdam: Amsterdam University Press.

Favell, A. (2013). The Changing Face of 'Integration' in a Mobile Europe. http:// www.adrianfavell.com/CESweb.pdf. Last view 01/09/2016.

Finch, J. (2007). Displaying Families. Sociology, 41(1), 65-81.

Finch, J. (2011). Exploring the Concept of Display in Family Relationships. In J. Seymour \& E. Dermott (Eds.), Displaying Families: A New Concept for the Sociology of Family Life (pp. 197-206). London: Palgrave Macmillan.

Fox, J. E., Moroşanu, L., \& Szilassy, E. (2015). Denying Discrimination: Status, 'Race', and the Whitening of Britain's New Europeans. Journal of Ethnic and Migration Studies, 4l(5), 729-748. https://doi.org/10.1080/13691 83X.2014.962491.

Huete, R., Mantecón, A., \& Estévez, J. (2013). Challenges in Lifestyle Migration Research: Reflections and Findings About the Spanish Crisis. Mobilities, 8(3), 331-348. https://doi.org/10.1080/17450101.2013.814236.

Iacob Larionescu, A. (2016). The House as Support of Gender Relations. Agathos, $7(2), 142-156$.

Kennedy, P. (2010). Mobility, Flexible Lifestyles and Cosmopolitanism: EU Postgraduates in Manchester. Journal of Ethnic and Migration Studies, 36(3), 465-482. https://doi.org/10.1080/13691830903426838.

Morgan, D. (2011). Rethinking Family Practices. London: Palgrave Macmillan. 
Pauli, J. (2008). A House of One's Own: Gender, Migration, and Residence in Rural Mexico. American Ethnologist, 35(1), 171-187.

Ralph, D. (2015). Work, Family and Commuting in Europe. London: Palgrave Macmillan.

Ryan, L., \& Mulholland, J. (2014). Trading Places: French Highly Skilled Migrants Negotiating Mobility and Emplacement in London. Journal of Ethnic and Migration Studies, 40(4), 584-600. https://doi.org/10.1080/13691 83X.2013.787514.

Torkington, K. (2012). Place and Lifestyle Migration: The Discursive Construction of 'Glocal' Place-Identity. Mobilities, 7(1), 71-92. https://doi.org/10.1080/ 17450101.2012 .631812 .

Open Access This chapter is licensed under the terms of the Creative Commons Attribution 4.0 International License (http://creativecommons.org/licenses/ by $/ 4.0 /$ ), which permits use, sharing, adaptation, distribution and reproduction in any medium or format, as long as you give appropriate credit to the original author(s) and the source, provide a link to the Creative Commons license and indicate if changes were made.

The images or other third party material in this chapter are included in the chapter's Creative Commons license, unless indicated otherwise in a credit line to the material. If material is not included in the chapter's Creative Commons license and your intended use is not permitted by statutory regulation or exceeds the permitted use, you will need to obtain permission directly from the copyright holder.

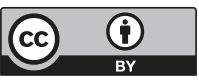

